\title{
Distribution and ecology of Carex secalina in the Czech Republic and Slovakia
}

\author{
Pavol Eliášs ${ }^{*}$, Vít Grulich², Daniel Dítě ${ }^{3}$ Dušan Senko ${ }^{3}$ \\ 1 Department of Botany, Slovak University of Agriculture, Tr. A. Hlinku 2, 94976 Nitra, Slovakia \\ ${ }^{2}$ Institute of Botany and Zoology, Masaryk University, Kotlárská 2, 61137 Brno, Czech Republic \\ ${ }^{3}$ Institute of Botany, Slovak Academy of Sciences, Dúbravská cesta 9, 84523 Bratislava, Slovakia
}

\begin{abstract}
Current and historical occurrence as well as coenotic affinity and ecology of Carex secalina in the Czech Republic and Slovakia are presented. The study is based on revision of herbarium specimens from 25 herbaria, literature data excerption and a field survey carried out during 2004-2010. Altogether, 168 sites were documented in the Czech Republic divided to two separate areas. Stabile occurrence trend was found in last decades, because 45 localities were documented in period 1975-1999 (27\% of sites) and recent occurrence was confirmed at 42 localities (24\% of sites). On the basis of our current knowledge the species was included into the IUCN threat category VU (vulnerable). In Slovakia, 19 localities of the species were recorded in total, but only 4 sites were confirmed recently ( $21 \%$ of sites recorded). However, only a small number of individuals was recorded there (less than 50 individuals in total) and half of this sites is acutely threatened by destruction (ploughing, secondary succession). Therefore, the C. secalina status in the Slovak Red List was changed to the IUCN category "critically endangered" (CR). Results of the study are summarised in the maps of historical and current species distribution. C. secalina usually occurred in halophytic grassland communities, especially in association Agrostio stoloniferae-Juncetum ranarii Vicherek 1962. However, it may occur in many other communities which suggest that the species had not well-defined coenotic relationships. On the basis of our knowledge, we consider C. secalina as an obligate halophyte.
\end{abstract}

Keywords: Carex, halophytes, IUCN criteria, occurrence, rare species

\section{Introduction}

Carex secalina occurs in natural habitats especially in humid salty meadows and pastures, usually in stands of class Festuco-Puccinellieta and Scorzonero-Juncetea. It is also found on the shores of salt lakes [1,2]. On the other hand, it is not rare in secondary habitats on salt-affected soils, such as abandoned field edges, field inundations, cart-roads, exposed shores of man-made dams and mining pits bottoms [3]. The species is considered as an obligate halophyte [4-6].

So the species prefers inland saline habitats, which are designated as priority habitats in Europe, and are included in the NATURA 2000 network. In Central Europe, this type of habitats is located especially in the Pannonian biogeographical region; Molnár [7] considered them as the westernmost part of the Eurasian steppe zone and they belong to the most typical inland saline habitats developed in Europe, excluding the former Soviet Union.

*Corresponding author. Email: pavol.elias.jun@gmail.com

This is an Open Access digital version of the article distributed under the terms of the Creative Commons Attribution 3.0 License (creativecommons.org/licenses/by/3.0/), which permits redistribution, commercial and non-commercial, provided that the article is properly cited.
The greatest extent of such habitats is in Hungary, where their area is estimated at about 400000 hectares [8]. Outside Hungary, inland saline habitats are situated on the edges of the Pannonian Basin in the Czech Republic (southern Moravia), Lower Austria, in the Serbian province of Voyvodina, in southern Slovakia and in Transcarpathian Ruthenia (Ukraine), Romania and north-eastern Croatia [9]. Salt marshes with similar vegetation occur even in Bulgaria [10].

Carex secalina is a species with a relatively large, but disjunctive Eurasian distribution range - it occurs in central, eastern and south-eastern Europe, the Caucasus, Iran, Central Asia and south-eastern Siberia as far as Lake Baikal $[11,12]$. The species is protected under the Bern Convention on the Conservation of European Wildlife and Natural Habitats [13]. In Central Europe the species is relatively abundant only in Hungary [14,15] and Germany [12], although it is classified as an endangered species in the latter country [16]. In other countries of this region it is considered to be endangered (Austria, Czech Republic, Slovakia) [17-20] or critically endangered (Poland) [21]. However, detailed data about historical and recent occurrence were published only in Poland [22].

In view of the foregoing contributions, the paper aims: (i) to obtain historical and current information concerning the occurrence of Carex secalina in the Czech Republic and Slovakia and (ii) to assess the ecological requirements and coenotic affinity of the species. 


\section{Material and methods}

Carex secalina Wahlenb. is a member of subgenus Carex and section Secalinae (O. Lang) Kuk. 1909 including only three sedge taxa [23]. Recently, Ciocârlan [24] divided the species to two subspecies: subsp. secalina and subsp. sabulosa Ciocârlan. The nominate subsp. secalina is represented by plants of 10-40 $\mathrm{cm}$ in height, having male spikelets $2-3$ in number. The latter subspecies, subsp. sabulosa is represented by low plants, of 5-8 $\mathrm{cm}$ in height, with a quite developed radicular system and male spikelets 1 in number. This intraspecific subdivision is not yet fully accepted and exact knowledge about occurrence of both subspecies are insufficient today.

Carex secalina Wahlenb. is a plants of $10-30 \mathrm{~cm}$ in height, having male spikelets 2-3 in number, female spikelets 2-5 in number, inserted by one in a row, distanced, on stems, or inserted tightly, 2-5 in a row on secondary branches, utricles 5-7 mm long, not arranged in distinct rows $[24,25]$. The species is very often confused with Carex hordeistichos Vill. C. hordeistichos is characterised especially by sparsely pubescent utricles, 8-12 mm long, arranged in distinct rows [26].

The research was undertaken in 2004-2010. We designed the distribution by studying the herbarium specimens from the herbaria BP, BBZ, BRA, BRNM, BRNU, CB, KO, LTM, MMI, MZ, NI, NJM, OL, OLM, PMK, PR, PRC, ROZ, SAV, SLO, TM, TMM, VM, VYM, and ZV, and literature data as well as conducting field research. All data on the occurrence of Carex secalina are divided into three groups: the first includes all the historical data from the literature and herbaria to year 1975, the second group includes data from literature and herbaria for the period of intensive land reclamation and drainage projects in the years 1975-1999, and the third group includes current relevant data found during our research as well as that published in the literature after 2000. The last period is relatively short, because it considers only the period after the publication of recent versions of Red Lists of vascular plants in the Czech Republic and Slovakia [18-20]. This last period (after 2000) includes the most current relevant data on the occurrence of the species.

All herbarium data without precise dating (e.g. Makowsky s. a. BRNU, PRC) originated in the 19th and early 20th centuries; we include them in the period marked "until 1975". Herbarium specimens collected during field research are stored in herbarium BRNU and/or NI. Coordinates of recent localities were obtained during field research using GPS equipment Garmin CS 60, coordinates of other localities were taken from Google Earth. A list of localities (see Appendix S1) is compiled according to directives of the Flóra Slovenska VI/1 [27].

Data concerning ecological requirements of the species were collected by our own field observations and analysis of the soil maps published in the Landscape Atlases of the Czech Republic and Slovak Republic [28,29]. We also use analyses of floristic composition of visited localities and occurrence of other obligate halophytes in Carex secalina stands (e.g. Crypsis aculeata, Plantago maritima, and Puccinellia distans agg.).

Nomenclature of plant taxa was unified according to Marhold and Hindák [30]. Syntaxa names were not unified according to a single source and therefore they are cited including the author names. Phytogeographical division of the Czech Republic is based on Skalický [31], and in Slovakia followed Futák [32]. Herbarium abbreviations were excerpted from Holmgren et al. [33] and Vozárová and Sutorý [34]. Categories of threat were determined according to the methodology of IUCN [35].

\section{Results}

\section{Distribution of Carex secalina in the Czech Republic}

Carex secalina has appeared in the Czech Republic in a total of 169 localities (Fig. 1, Fig. 2, Fig. 3, Appendix S1) in two isolated areas: $(\boldsymbol{i})$ in the lowlands and hilly areas of northern and central Bohemia (104 localities) and (ii) in southern Moravia (65 localities). All known sites are located in the phytogeographical area of thermophyticum. Sites are located in lowlands and uplands. The minimum altitude site is located near the village of Píśtany (145 $\mathrm{m}$ a.s.l.); maximum altitude was recorded in $280 \mathrm{~m}$ a.s.l. at the foothill of the Oblík Hill near the village of Raná.

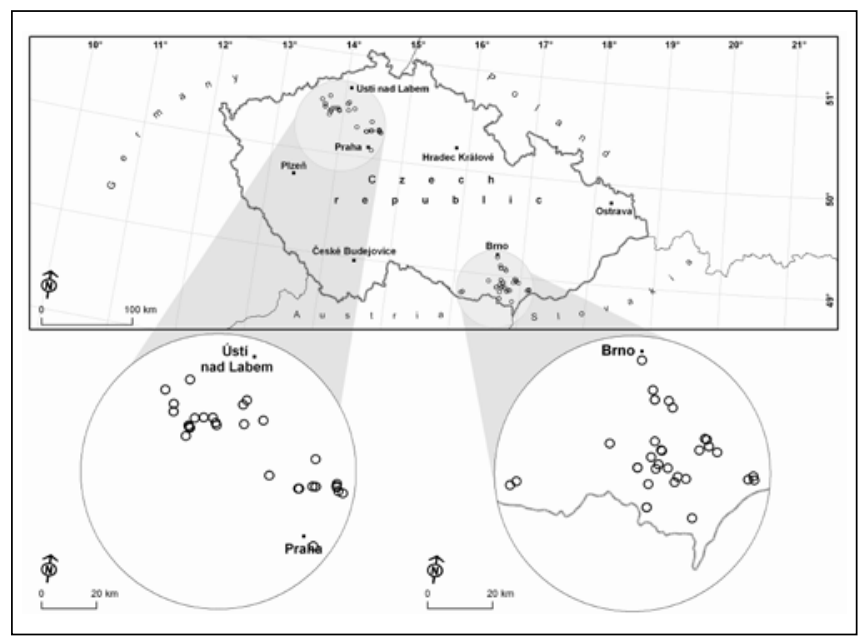

Fig. 1 Historical distribution of Carex secalina in the Czech Republic (until 1975).

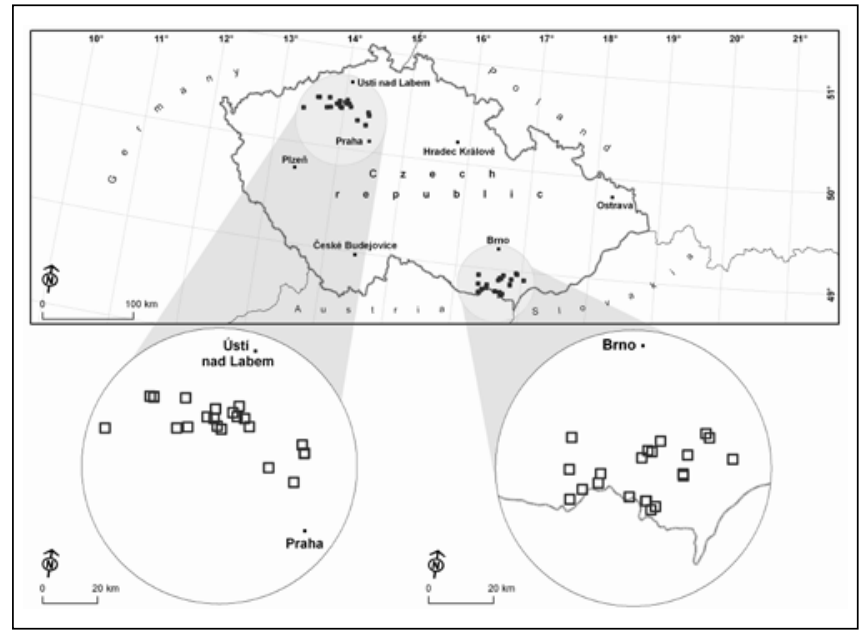

Fig. 2 Historical distribution of Carex secalina in the Czech Republic (1975-1999).

The historical occurrence in Bohemia comprised a relatively large area in western and north-western Bohemia (eastern foothills of the Doupovské hory Hills, Roudnice nad Labem region, and western parts of the Strední Polabí area).

Exclave historical occurrence out of saline habitats was recorded in the 1950s on the eastern edge of Prague. It is a matter of speculation whether the species was introduced here 
secondarily or if it was native to this locality. In Moravia, the occurrence of Carex secalina is bounded by surrounding of settlements of Znojmo and Brno, hills west and south of the Ždánický les Hills and in the south by the border with Austria. A rather isolated group of sites was found in the vicinity of Hodonín, but the largest conglomeration of localities was recorded in the territory of the former salt marshes south and southeast of Brno (Měnín, Klobouky u Brna, Čejč, Hustopeče, Mikulov, Sedlec and Rakvice; Fig. 1, Fig. 2, Fig. 3).

Current occurrence of the species in the Czech Republic was confirmed in 42 localities (24\% of all localities recorded). Most of sites (40) were concentrated in the lowlands and hills of Bohemia in regions southwest of Prague (in the surroundings of Žatec, Most and Louny). Only two localities of current occurrence were found in southern Moravia (Vrbovec, Sedlec).

The trend of occurrence reduction of C. secalina in Czech Republic showed that most of localities were destroyed in period after 1975. Later, the decrease of number of $C$. secalina sites was very slight and number of existing sites has been practically stable over the past 10 years. In addition, many populations are large, including hundreds of individuals. Therefore, by applying the IUCN criteria, we propose to revise the current status of the species EN ("endangered") into category VU ("vulnerable").

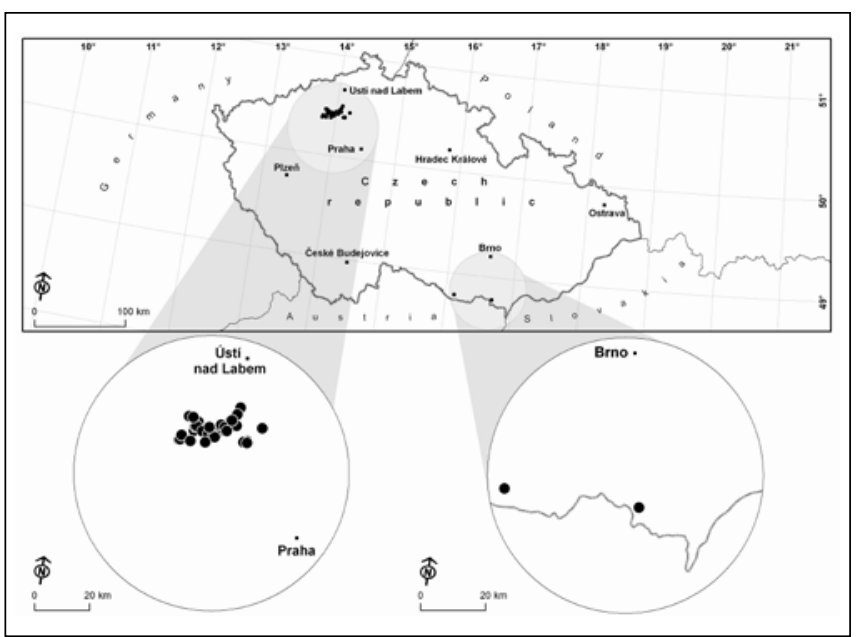

Fig. 3 Recent distribution of Carex secalina in the Czech Republic (2000 onwards).

\section{Distribution of Carex secalina in Slovakia}

In Slovakia, Carex secalina has always occurred much less frequently than in the Czech Republic (Fig. 4). Altogether, 19 localities were found especially in the lowlands of the south and south-western part of Pannonia in the phytogeographical districts of the Záhorská nížina Lowland and the Podunajská nížina Lowland. The centre of distribution was in the Podunajská nížina Lowland in the area between the towns of Bratislava, Nitra and Štúrovo (17 localities in total). Only one site was found at the beginning of 20th century in the Záhorská nížina Lowland near the Moravský Svätý Ján village, however, it was destroyed. A single locality was also found in the Carpathians in Spišské Podhradie village (the Spišská kotlina Basin) within the same time period. Occurrence of the species was never again confirmed there, therefore (despite the existence of a herbarium voucher) it is not entirely clear whether Carex secalina ever really occurred there (exchange of herbarium labels?) or whether the population was destroyed not long after discovery.

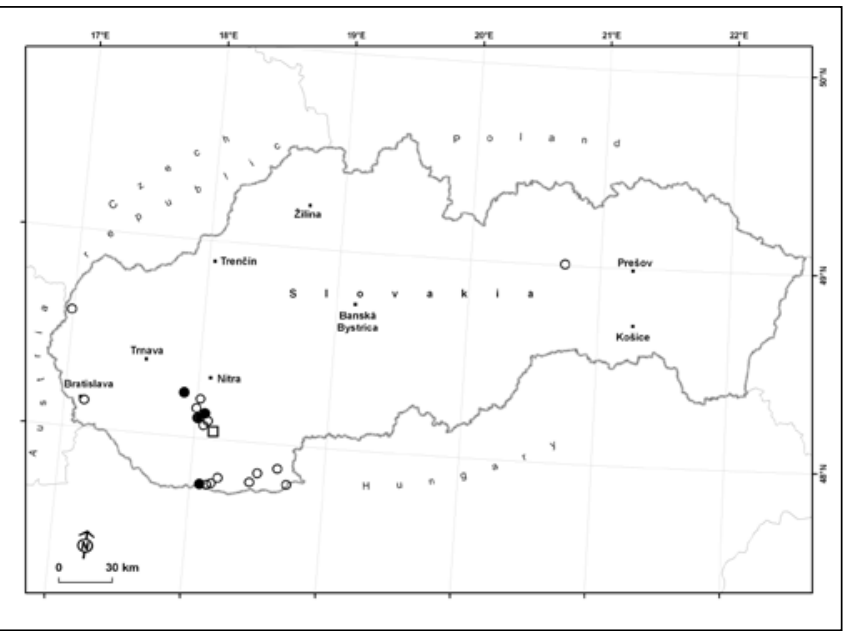

Fig. 4 Historical and recent distribution of Carex secalina in Slovakia until 1975 (white circles), in 1975-1999 (white squares), and 2000 onwards (black circles).

The lowest known site is located at an altitude of $105 \mathrm{~m}$ a.s.l. (Komárno); maximum altitude was found at $132 \mathrm{~m}$ a.s.l. (Mojmírovce) and ca. 430-450 m a.s.l. (Spišské Podhradie) respectively.

At present, Carex secalina occurs very rarely only in the Podunajská Nižina Lowland in the remains of strongly changed (ruderalized) halophytic vegetation. We confirmed four locations in the surroundings of Močenok, Tvrdošovce and Komárno. The size of these remaining current populations was small. The largest Slovak population on the bank of the Ráczove jazierko pool in the Tvrdošovce village comprised only 37 individuals (tussocks) in 2010. The locality is threatened by expansion of Phragmites australis and human impact. The pool has been used as fish pond since 2009, the fluctuation of water level has been stopped and the banks were afforested by Salix matsudana "Tortuosa" (!). Additional populations on the banks of a small pool near the Tvrdošovce railway stop and a population in an abandoned field depression near the Nová Stráž farmstead (west from the Komárno town) included only 7 individuals. The last one, a small-size population (3 individuals) located in an arable field inundation in Siky farmstead near Močenok settlement was ploughed in 2008, but it is likely that the species could be found in saline pastures surrounding this field.

Comparing numbers of $C$. secalina localities in Slovakia we concluded that most of the sites were destroyed in the past (79\%) and half of recent sites are acutely threatened by destruction (ploughing, secondary succession). Therefore, we propose to reclassify the species from IUCN category EN ("endangered") to CR ("critically endangered"). Ex situ cultivation has been carried out by the Botanical Garden of Slovak University of Agriculture in Nitra (3 individuals were taken from the largest population in Tvrdošovce in 2009).

\section{Ecological requirements}

In the Czech Republic and Slovakia, the presence of Carex secalina almost perfectly reflects the extension of saline soils. In the Czech Republic, it is clearly related to the sedimentary, mineral-rich bedrocks (usually of marine sediments), which form heavy soils. In these areas, moreover, there are mineral springs with a high content of chloride and magnesium salts (in the surroundings of the villages of Zaječice, Šaratice, Čejč, 
and Sedlec). Those sites are situated in the warmest and driest areas with more significant rainfall during the spring, which causes capillary infiltration of mineral-rich water to the surface horizons of soils. Salinity of this soil increased by raised evaporation, and salt efflorescences are created in some cases. In Slovakia, the occurrence is mainly related to solonetz and solonchak soils in dry and warm lowland areas; occurrences in localities around mineral springs have been reported rarely (Spišská Kotlina Basin). On the basis of our knowledge, we consider C. secalina as an obligate halophyte.

In the above-mentioned areas, the species occurs in native saline habitats (saline pastures and meadows, banks of saline lakes) together with other common halophytes (e.g. Juncus gerardii, Plantago maritima and Spergularia salina), but it is quite often accompanied by disturbed and ruderalized subhalophytic and halophytic sites. These include for example periodically drying field depressions, old fallows in former salt marshes and stands of perennial forage crops such as Lucerne (Medicago sativa). The relationship of C. secalina to disturbed plots is illustrated by the biological characteristics of that type of sedge. Together with Carex hordeistichos, the species is usually short-lived and its life cycle is well-connected with species found in sites with a low cover of long-lived perennial competitors.

\section{Discussion}

\section{Distribution in the Czech Republic and in Slovakia}

The first comprehensive information on the occurrence of Carex secalina in the Czech Republic was given by Podpera [36] for southern Moravia. Much later, Moravec [37] described the species' distribution in west and north-western Bohemia (surrounding of Všetaty, Velvary, Lower Poohří, riverbed of Bílina river) and in south-eastern Moravia (Dyjskosvratecký Úval area and the surroundings of Hodonín). Detailed distribution in Bohemia was summarized and commented upon by Holub and Houfek [38] and Sládek [6]. Dostál [3] published occurrences for the whole country, but those data are incomplete and characterize the distribution of $C$. secalina only superficially. Since then, knowledge of Carex secalina distribution has not markedly increased in the Czech Republic, and information concerning the other localities has been recorded only in the wider area of previously known sites [26,39]. Recently, most relevant localities were found in north-western Bohemia (in the regions of Žatec, Most and Louny) northwest of Prague [40]. On the other hand, only two localities have been currently confirmed in southern Moravia (Vrbovec, Sedlec).

In Slovakia, more detailed distribution data were published by Moravec [37] and later by Dostál and Červenka [41]. Both works pointed out the occurrence of the species in the Záhorská Nížina Lowland (Moravský Svätý Ján), in the southern part of the Ponitrie region (Podunajská Nižina Lowland) and near Blatnica in the Turčianska Kotlina Basin (West Carpathians). As we found, these data are very inaccurate. In addition to the correctly noted occurrences in the Záhorská Nížina Lowland and in the south of Nitra, the species was also found near Bratislava and around Štúrovo (Fig. 4). Currently, the species survives only in the broad surroundings of Nitra (Močenok), Nové Zámky (Tvrdošovce) and Komárno (Nová Stráž). In the West Carpathians, the information regarding species occurrence near Blatnica (the Turčianska Kotlina Basin) published by Margittai [42] and Dostál and Červenka [41] is inaccurate. As we found during our study of herbarium material in the herbarium of the Natural History Museum in Budapest (BP), Margittai collected the very similar species Carex hordeistichos Vill. near Blatnica, but he identified it as C. secalina. Carex hordeistichos is still relatively abundant in the Turčianska Kotlina Basin, and it is often confused with C. secalina $[43,44]$. In the West Carpathians, the species was collected only once by Legyel around the Spišské Podhradie village in the early 20th century. To resolve the question of whether or not the species actually occurred in the Spiš Region is almost impossible today. It is certain that suitable habitat with a higher salt content still exists near the village in the form of the Sivá Brada mineral spring. Obligate halophytes such as Glaux maritima, Plantago maritima, and Scorzonera parviflora are still present there [45]. On the other hand, the species was never reliably confirmed on the site (or elsewhere in the West Carpathians) despite many and detailed floristic and phytosociological studies (e.g. [45-48]). Two explanations are possible: $(\boldsymbol{i})$ either the species is extinct on the site or (ii) the herbarium labels were exchanged. This is plausible because Lengyel also collected Carex secalina during this period near Novi Sad and Zrenjanin in the Banat Region (N Serbia, vouchers are stored in the herbarium BP).

Some localities of Carex secalina disappeared in the late 19th and early 20th century. These losses were mostly random, but some were associated with the first attempts of land reclamation of halophytic habitats e.g. in south-eastern Moravia [49]. However, the obvious decrease of Carex secalina localities in the Czech Republic and Slovakia was caused by massive changes in land use especially during communist era (19481989). Saline habitats, for many years used as extensive pastures, were changed to arable land, building plots or afforested in the 1970s and 1980s [50,51]. The last remnants of saline habitats were either declared nature reservations or abandoned and left to their fate. The grazing was stopped in both cases, resulting in the disappearance or significant weakening of the size of local Carex secalina populations. The dependence of many halophytes upon grazing is generally known. This type of habitat management causes, e.g. a decrease of competition from tall-growing non-halophytic species, while trampling and disturbance of vegetation cover creates micro-areas suitable for the germination of new individuals of halophytes, and animals enrich the soil with nutrients [9,52-57]. The key impact of grazing on Carex secalina survival was clearly confirmed by Lembicz et al. [22]. The authors found a positive correlation between population size of the species and grazing intensity. Other significant factors enhancing the germination efficiency were diaspore trampling into the ground by animal hooves, and the high generative reproduction abilities of individuals (individuals producing large amounts of seeds) [58].

As our data show, the number of Carex secalina localities was several times higher in the Czech Republic than in Slovakia despite the fact that in Slovakia the halophilous vegetation is better developed than in the Czech Republic. We believe that the reason is a highly disjunctive distribution range of Carex secalina, rather than favourable environmental conditions. The species occurs in scattered and isolated localities throughout Europe and Asia [11]; the large westernmost isolated portion is situated in Germany, the Czech Republic, Austria and Hungary. This isolated part of the distribution range of $C$. secalina reaches only marginally to Moravia, Slovakia and Poland, therefore C. secalina is a very rare species in these regions/ countries [3,22]. 


\section{Ecology and Coenotic affinity}

Krist [5] considered the species as an obligate halophyte. An obligate halophyte is defined as a plant with optimal growth on habitats with moderate or high salinity levels and incapable of growing at a low salinity level $[59,60]$. Carex secalina has usually been reported in native or semi-ruderal saline habitats such as wet saline meadows, the banks of salt lakes, the edges of saline fields, saline waterlogged disturbed areas, edges of rural roads, banks of mining pits, etc. $[3,12,22,39,41,61,62]$. This habitat characteristic corresponds well with the definition of an obligatory halophyte. Sometimes it survives also in non-saline ruderal habitats [22,63]. Survival of obligate halophytes at ruderal locations without significant salinization, however, has been recorded - for example in the case of species Pholiurus pannonicus [64].

Barbour [65] considered the ability to reproduce, rather than short-term growth, to be the ultimate criterion of obligate halophytes. According to our knowledge, Carex secalina is capable of reproducing generatively on soils with high salt concentrations on the banks of the Neusiedler See (NE Austria) as well as on the banks of a small pond in Tvrdošovce (SW Slovakia) together with other obligate halophytes as Crypsis aculeata, Plantago maritima, and Puccinellia distans. As we have previously found, the species has occurred on highly salt-affected solontchak and solonetz soils, where electric conductivity reached values of $1.7-6.2 \mathrm{mS} \times \mathrm{cm}^{-1}$ [66]. On the other hand, Žukowski et al. [58] pointed out that enlarging of C. secalina areas in Poland could be restricted by inhibition of germination and seedling survival due to high salinity of soil. But the authors noted that this hypothesis needs verification. Novák [67] mentioned that salinity of habitats could be not the most important factor influencing the occurrence of C. secalina, because the species especially requires habitats with plenty of moisture and natural (water level fluctuation) or artificial (grazing, agricultural activities) disturbance of vegetation cover.

In the Czech Republic, Carex secalina is considered as a dominant species of association Agrostio stoloniferaeJuncetum ranarii Vicherek 1962 belonging to alliance Agropyro-Rumicion crispi Nordh. 1940 em. R. Tx. 1950. It was also incidentally recorded in another association of this alliance - Loto-Potentilletum anserinae Vicherek 1973 and also in association Astero pannonici-Bolboschoenetum compacti Hejný et Vicherek ex Otahelová et Valachovič in Valachovič 2001 (syn. Bolboschoenetum maritimi Soó 1927) from alliance Meliloto dentati-Bolboschoenion maritimi Hroudová et al. 2009 (syn. Scirpion maritimi Dahl et. Hadač 1941) $[48,68]$.

Agrostio stoloniferae-Juncetum ranarii is a secondary community, which is related to the disturbances of soil and vegetation cover. It has occurred at locations with high soil salt content - in wet inundations, edges of fields, shores of ponds, and in the vicinity of mineral springs. Most of the sites are located on anthropogenic habitats. Besides halophytes, ruderal and wetland grasslands species are represented in the association. These stands are heterogeneous with mosaic character [61]. In the Czech Republic, where the association reaches the northwestern margin of its distribution range, the sites are known in the Podboransko region, the lower Poohří area [61] and in southern Moravia [48]. Vicherek [48] mentioned the presence of the community in Slovakia as well, but Dítě et al. [69] did not verify this. We recorded current occurrences in the residues of ruderalized saline plant communities in Slovakia, which cannot be clearly included in a particular plant association. Together with $C$. secalina we recorded here some halophytes, e.g. Heleochloa schoenoides, Lotus tenuis, Spergularia media, and Tripolium pannonicum and also a mixture of mesophilic and ruderal species. Similar findings have been made in Poland, where the species was usually found in various plant communities of alliance Agropyro-Rumicion crispi Nordh. 1940 em. R. Tx. 1950 as well as in vegetation patches covered by species characteristic of classes Juncetea maritimi Br.-Bl. ex Tüxen et Oberdorfer 1958, Bidentetea tripartiti R. Tx. et al. in R. Tx. 1950, Phragmitetea australis R. Tx. et Preisg. 1942 and Molinio-Arrhenatherea Tüxen 1937 em. 1970 [22]. By contrast, Moysienko et al. [62] pointed out C. secalina only in three typical saline associations of alliances Scorzonero-Juncion gerardii (Wendelberger 1943) Vicherek 1973 and Puccinellion limosae Soó 1933 em. Vicherek 1973 in Ukraine. Moreover, Ellenberg [70] considered the species as characteristic for saltwater coast vegetation of Asteretalia tripolii. All of the above-mentioned data shows that the species has no welldefined coenotic affinities, and further detailed research is needed. Nevertheless, we can conclude that Carex secalina prefers plant communities developed in more or less saline soils of natural and/or man-made habitats. A common feature of these communities (except for the above-mentioned higher salt content of the soil) is a mainly continental climate characterized by significant annual variation in temperature, and relatively moderate precipitation occurring mostly in summer. Holub [71] considered C. secalina as a species with an infraseptentrio-Euro-Siberian type of distribution range; its presence correlates strongly with the continental climate [67]. It is also clear from the map of distribution range published by Meusel at al. [11], that while the western part of the distribution range is very fragmented; the eastern part (from about $60^{\circ}$ East longitude) has a more or less compact character [23]. Significant "holes" in the species' occurrence in Ukraine, Belarus and south-western Russia may be due to lack of suitable habitat, but they could be also connected with current landscape use, poorly explored large territory or even the preference of botanists for research of only certain habitat types.

\section{Acknowledgements}

We wish to thank the management of the Department of Higher Plant Taxonomy of the Botanical Institute, Slovak Academy of Sciences for providing data from a database of distribution of vascular plants and to two anonymous reviewers for valuable comments to the earlier versions of this paper. We are also indebted to Silvia Herianová and Scott Burgess for language correction. The research was funded by the grant project of the Slovak Ministry of Education VEGA 2/ 0030/ 09 and 2/ 0003/ 12.

\section{Supplementary material}

The following supplementary material for this article is available online at https://pbsociety.org.pl/journals/index.php/ asbp/rt/suppFiles/119/ 0:

1. Appendix S1. List of localities of Carex secalina in the Czech Republic and Slovakia. 


\section{References}

1. Mucina L. Puccinellio-Salicornietea. In: Mucina L, Grabherr G, Ellmauer T, editors. Die Pflanzengesellschaften Österreichs. Teil 1. Anthropogene Vegetation. Stuttgart: Fischer; 1993. p. 522-549.

2. Borhidi A. A Magyar flóra szociális magatartás típusai, természetességi és relatív ökológiai értékszámai. Pécs: Janus Pannonius Tudományegyetem Növénytani Tanszék; 1993.

3. Dostál J. Nová květena ČSSR. Prague: Academia; 1989. (vol 2).

4. Borhidi A. Magyarország Növénytársulásai. Budapest: Akadémiai Kiadó; 2003.

5. Krist V. Halofytní vegetace jz. Slovenska a severní části Malé Uherské nížiny. Práce Mor Přír Společn Brno. 1940;12(10):1-100.

6. Sládek J. Carex secalina Wahlenb. v Čechách. Severočes Př́r. 1996;29:27-34.

7. Molnár Z. The land-use historical approach to study vegetation history at the century scale. In: Tóth E, Horváth R, editors. Proceedings of "Research, conservation, management" conference. Aggtelek: Aggteleki Nemzeti Park Igazgatóság; 1997. p. 345-354.

8. Szabolcs I. Salt-affected soils in Europe. Hague: Martinus Nijhoff; 1974.

9. Dítě $\mathrm{D}$, Melečková Z, Eliáš $\mathrm{P}$, Janák M. Manažmentový model pre biotopy slaných pôd. Bratislava: DAPHNE Inštitút Aplikovanej Ekológie; 2011.

10. Tzonev R, Lysenko T, Gusev C, Zhelev P. The halophytic vegetation in south-east Bulgaria and along the Black Sea coast. Hacquetia. 2008;7(2):95-121. http://dx.doi. org/10.2478/v10028-008-0006-3

11. Meusel H, Jäger EJ, Weinert E. Vergleichende Chorologie der Zentraleropäischen Flora. Jena: Fischer; 1965. (vol 1).

12. Schulze-Motel W. Carex L. In: Hegi G, editor. Illustrierte Flora von Mitteleuropa. Hamburg: Parey Buchverlag; 1980. p. 96-274.

13. Oznámenie Ministerstva zahraničných vecí Slovenskej republiky č. 93/1998 Z.z. Bratislava: Iura Edition; 1998.

14. Soó R. A magyar flóra és vegetáció rendszertani-növényföldrajzi kézikönyve. Budapest: Akadémiai Kiadó; 1973. (vol 5).

15. Lájer K. Cyperaceae - Palkafélék családja. In: Király G, editor. Új magyar füvészkönyv. Magyarország hajtásos növényei. Határozókulcsok. Aggtelek: Aggteleki Nemzeti Park Igazgatóság; 2009. p. 545-570.

16. Korneck D, Schnittler M, Vollmer I. Rote Liste der Farnund Blütenpflanzen (Pteridophyta et Spermatophyta) Deutschlands. In: Schriftenreihe für Vegetationskunde. 1996. (vol 28).

17. Niklfeld H, Schratt-Ehrendorfer L. Rote Liste gefährdeter Farn- und Blütenpflanzen (Pteridophyta und Spermatophyta) Österreichs. 2. Fassung. In: Niklfeld H, editor. Rote Listen gefährdeter Pflanzen Österreichs. Vienna: Grüne Reihe des Bundesministerium für Umwelt, Jugend und Familie; 1999. p. 33-151.

18. Holub J, Procházka F. Red list of vascular plants of the Czech Republic - 2000. Preslia. 2000;72:187-230.

19. Procházka F. Černý a červený seznam cévnatých rostin České republiky (stav v roce 2000). Příroda. 2001;18:1-146.

20. Feráková V, Maglocký Š, Marhold K. Červený zoznam paprad’orastov a semenných rastlín Slovenska. Ochr Prír. 2001;20 suppl:44-77.
21. Chmiel J, Lembicz M, Żukowski W. Carex secalina Willd. ex Wahlenb. Turzyca żytowata. In: Kaźmierczakowa R, Zarzycki K, editors. Polska czerwona księga roślin. Paprotniki i rośliny kwiatowe. Kraków: W. Szafer Institute of Botany, Polish Academy of Sciences; 2001. p. 508-510.

22. Lembicz M, Bogdanowicz AM, Chmiel J, Żukowski W. Carex secalina (Cyperaceae), a critically endangered species of Europe: historic and new localities in Poland. Acta Soc Bot Pol. 2009;78(4):311-320.

23. Egorova TV. Sedges (Carex L.) of Russia and adjacent states within the limits of the former USSR. Saint Luis: ChemicalPharmaceutical Academy, Saint Petersburg \& Missouri Botanical Garden Press; 1999.

24. Ciocârlan V. The variability of the species Carex secalina Willd. ex Wahlenb. Bul Grâd Bot Iaşi. 2006;13:59-62.

25. Chater AO. Carex L. In: Tutin TG, Heywood VH, Burges NA, Moore DM, Valentine DH, Walters SM, et al., editors. Flora Europaea. Cambridge: Cambridge University Press; 1980. p. 290-323. (vol 5).

26. Grulich V, Repka R. Carex. In: Kubát K, Hrouda L, Chrtek jun. J, Kaplan Z, Kirschner J, Štěpánek J, editors. Klíc ke kvetene Ceské republiky. Prague: Academia; 2002.

27. Goliašová K, Šípošová $H$, editors. Flóra Slovenska. Bratislava: Veda; 2008. (vol 6/1).

28. Hrnčiarová T, Mackovčin P, Zvara I, editors. Atlas krajiny České republiky. Prague: Ministerstvo zivotního prostredí České republiky; 2010.

29. Miklós L, Hrnčiarová T, editors. Atlas krajiny Slovenskej republiky. Bratislava: MŽP SR; 2002.

30. Marhold K, Hindák F. Checklist of non-vascular and vascular plants of Slovakia. Bratislava: Veda; 1998.

31. Skalický V, Hejný S. Regionálně fytogeografické členění. In: Slavík B, editor. Květena České republiky. Praha: Academia; 1988. p. 103-121. (vol 1).

32. Futák J. Flóra Slovenska. In: Bertová L, editor. Bratislava: Veda; 1984. p. 418-420. (vol IV/1).

33. Holmgren PK, Holmgren NH, Barnett LC. Index herbariorum. The herbaria of the world. 8th ed. New York: New York Botanical Gardens; 1990. (vol 1).

34. Vozárová M, Sutorý K, editors. Index herbariorum Reipublicae bohemicae et Reipublicae slovacae. Bull Slov Bot Spoločn. 2001;7 suppl:1-95.

35. IUCN. IUCN Red List categories and criteria: version 3.1 [Internet]. Gland: IUCN Species Survival Commission; 2001 [cited 2010 May 20]. Available from: http://www.iucnredlist.org/technical-documents/ categories-and-criteria/2001-categories-criteria

36. Podpěra J. Květena Moravy ve vztazích systematických a geobotanických. Fasc. 6/3. Práce Morav Přír Společn. 1928;5:57-415.

37. Moravec J. Carex L. - ostřice. In: Dostál J, editor. Květena ČSR. Prague: Přírodovědecké nakladatelství; 1950. p. 1848-1915.

38. Holub J, Houfek J. Carex secalina Wahlenb. Severočes Přír. 1978;8-9:90-94.

39. Řepka R. Mokřadní ostřrice České republiky. Prague: ČSOP; 2007.

40. Novák J. Rozšíření halofytů v dolním Poohří. Severočes Př́r. 2002;33-34:111-124.

41. Dostál J, Červenka M. Velký klúč na určovanie vyšších rastlín II. Bratislava: SPN; 1992.

42. Margittai A. Adatok Turóczvármegye flórajához IV. Magyar Bot Lapok. 1913;13:72-81. 
43. Bernátová D, Kliment J, Topercer J, Obuch J, Kučera P. Aktuálne poznatky o rozšírení a stave populácií niektorých prírodoochranne významných taxónov cievnatých rastlín, machorastov a chár v Turčianskej kotline. Ochr Prír. 2006;25:50-96.

44. Dítě D, Grulich V, Eliáš P. Contributions to the distribution and ecology of Carex hordeistichos in the Czech Republic and Slovakia. Biodiv Res Conserv. 2011;21:55-62.

45. Dítě D, Eliáš P, Sádovský M. Recentný výskyt halofytov v Liptovskej a Spišských kotlinách (severné Slovensko). Bull Slov Bot Spoločn. 2004;10 suppl:117-121.

46. Šmarda J. Vegetační poměry Spišské kotliny. Bratislava: SAV; 1961.

47. Vicherek J. Př́íspěvek k poznání Podtatranských lučních porostů. Biológia. 1956;11(6):345-349.

48. Vicherek J. Die Pflanzengsellschaften der Halophyten und Subhalophytenvegetation der Tschechoslowakei. Vegetace ČSSR ser A. 1973;5:1-200.

49. Grulich V. Slanomilné rostliny na jižní Moravě. Břeclav: ČSOP et Regionální Muzeum Mikulov; 1987.

50. Nováková J. Retreat of halophytes in the Czech Republic: agricultural, mining, and urbanization effects [the case of dentated melilot Melilotus dentata (Fabaceae)]. J Agri Environ Ethics. 1997;10(1):69-78. http://dx.doi. org/10.1023/A:1007731331212

51. Sádovský M, Eliáš P, Dítě D. Historické a súčasné rozšírenie slaniskových spoločenstiev na juhozápadnom Slovensku. Bull Slov Bot Spoločn. 2004;10 suppl:127-129.

52. Bakker JP, Dijkstra M, Russchen PT. Dispersal, germination and early establishment of halophytes and glycophytes on a grazed and abandoned salt-marsh gradient. New Phytol. 1985;101(2):291-308.

53. Bakker JP. The impact of grazing on plant communities, plant populations and soil conditions on salt marshes. Plant Ecol. 1985;62(1):391-398. http://dx.doi.org/10.1007/ BF00044766

54. Ungar I. Are biotic factors significant in influencing the distribution of halophytes in saline habitats? Bot Rev. 1998;64(2):176-199. http://dx.doi.org/10.1007/BF02856582

55. Molnár Z, Borhidi A. Hungarian alkali vegetation: origins, landscape history, syntaxonomy, conservation. Phytocoenologia. 2003;33(2):377-408. http://dx.doi. org/10.1127/0340-269X/2003/0033-0377

56. Loucougaray G, Bonis A, Bouzillé JB. Effects of grazing by horses and/or cattle on the diversity of coastal grasslands in western France. Biol Conserv. 2004;116(1):59-71. http:// dx.doi.org/10.1016/S0006-3207(03)00177-0

57. Fehér A. Origin and development of the salt steppes and marshes in SW Slovakia. Flora Pannonica. 2007;5:67-94.

58. Żukowski W, Lembicz M, Olejniczak P, Bogdanowicz A, Chmiel J, Rogowski A. Carex secalina (Cyperaceae), a species critically endangered in Europe: from propagule germination to propagule production. Acta Soc Bot Pol. 2005;74(2):141-147.

59. Ungar IA. Halophyte seed germination. Bot Rev. 1978;44(2):233-264. http://dx.doi.org/10.1007/BF02919080

60. Larcher W. Physiological plant ecology. Berlin: Springer; 1980.

61. Novák J, Šumberová K, Chytrý M. Slaniska s ostřicí žitnou (Agrostio stoloniferae-Juncetum ranarii Vicherek 1962). In: Vegetace ČR 1. Prague: Academia; 2007. p. 162-164.

62. Moysienko II, Solomakha VA, Solomakha TD. Carex secalina Willd. ex Wahlenb. (Cyperaceae) na Tiligulskomu limani. Ukr Bot Zh. 2009;66(1):35-43.

63. Hohla M. Flora der Bahnanlagen im Bereich von Schärding bis Wels. Öko-L. 1998;20(2):3-19.

64. Eliáš P, Dítě D, Grulich V, Šuvada R. Revision of historical and current distribution of Pholiurus pannonicus (Host.) Trin. in Slovakia. Hacquetia. 2010;9(2):177-183. http:// dx.doi.org/10.2478/v10028-010-0009-8

65. Barbour MG. Is any angiosperm an obligate halophyte? Am Midl Nat. 1970;84(1):105. http://dx.doi. org/10.2307/2423730

66. Dítě D, Eliáš P, Šuvada R, Szombathová N. Ecology and coenotic characteristics of the Pholiuro pannonici-Plantaginetum tenuiflorae Wendelberger 1943 in the Pannonian Basin. Phyton. 2010;49(2):293-313.

67. Novák J. Které podmínky prostředí významně ovlivňují česká slaniska? Severočes Př́r Litoměřice. 2000;32:37-43.

68. Hroudová Z, Hrivnák R, Chytrý M. Classification of inland Bolboschoenus-dominated vegetation in Central Europe. Phytocoenologia. 2009;39(2):205-215. http://dx.doi. org/10.1127/0340-269X/2009/0039-0205

69. Dítě D, Eliáš P, Šuvada R. Krátky komentovaný prehlad rastlinných spoločenstiev slanísk na Slovensku. Bull Slov Bot Spoločn. 32(2 suppl):107-112.

70. Ellenberg H. Vegetation ecology of Central Europe. 4th ed. Cambridge: Cambridge University Press; 1988.

71. Holub J. Fytogeografická analýza československých druhů rodu Carex. Zpr Čs Bot Společ. 1987;22(6):35-45. 